Ивушкин Александр Сергеевич

аспирант кафедры государственно-правовых дисциплин

Пензенского государственного университета

\section{СОЦИАЛЬНО-ЭКОНОМИЧЕСКИЕ ПРАВА В КОНТЕКСТЕ ТЕОРИИ ПУБЛИЧНОГО ПРАВА ЛОНА ФУЛЛЕРА И ДЖОНА ФИННИСА}

\section{Аннотация:}

Статья посвящена обоснованию естественноправовых характеристик категории социальноэкономических прав. Автор провел сравнительный анализ взглядов малоисследованных в России зарубежных авторов Л. Фуллера и Дж. Финниса, с одной стороны, и российских авторов (С.А. Авакьяна, М.В. Баглая и др.), с другой, и сделал вывод, что социально-экономические права должны быть основаны на базовых принципах права: ясности, исполнимости, стабильности и т. д. Эти принципы могуm работать только в единстве и опираться на такие социальные явления, как дружба, сотрудничество, взаимопомощь и социальная солидарность.

Ключевые слова:

социально-экономические права, естественные права, Конституция, доле, мораль, конституционное право, юридический позитивизм.
Ivushkin Aleksander Sergeyevich

PhD student, State and Legal Disciplines Department, Penza State University

\section{SOCIO-ECONOMIC RIGHTS IN THE CONTEXT OF LON FULLER'S AND JOHN FINNIS'S THEORIES OF PUBLIC LAW}

Summary:

The article justifies natural and legal characteristics of the category of socio-economic rights. The author carries out comparative analysis of L. Fuller's and J. Finnis's views, which are poorly studied in Russia, on the one hand, and Russian scholars (S.A. Avakiyan, M.V. Baglay and others), on the other hand, and concludes that the socio-economic rights should be grounded on the basic principles of law: clarity, enforceability, stability, etc. These principles can operate only in unity and base on such social phenomena as friendship, cooperation, mutual assistance and social solidarity.

Keywords: socio-economic rights, natural rights, Constitution, duty, morality, constitutional law, legal positivism.

Лон Фуллер [1] (1902-1978) по праву считается одним из самых сокрушительных критиков позитивистской доктрины права, основанной Джоном Остином и канонизированной Гансом Кельзеном и Гербертом Хартом. Юридический позитивизм лишь описывает наблюдаемые (позитивные) фракты без какой-либо попытки дать им моральную или идеологическую оценку. Такую методологическую установку Фуллер считает и лукавой, и идеологически заряженной.

По Фуллеру, как раз правила морального долга, а не моральных стремлений (в античном смысле) являются первичными социальными нормами, над которыми надстраиваются вторичные, включая нормы права. Нейтральный порядок позитивистов как таковой не будет «работать», если в нем нет внутренней морали, т. е. юридизированных минимальных стандартов справедливости, равенства, предсказуемости, стабильности и т. п.

Современный юснатурализм имеет немало именитых сторонников, но в качестве наиболее репрезентативного автора мы выбрали Джона Финниса (1940 г. р.) [2]. Он является новатором во многих отношениях. Например, он применяет необычную для юриспруденции методологию выбора и анализа материала. Так, вслед за Аристотелем Финнис проводит принципиальное различие между «центральным казусом» (Central Case) и «пограничными примерами» (Borderline Instances) [3]. В частности, Великобританию, Швецию или Данию альтернативно и в этом смысле произвольно исследователь может выбрать в качестве «центрального казуса», т. е. репрезентативного примера для «конституционной монархии». Как на «пограничный пример» он может сослаться на «королевство Иордания». Однако если исследователя интересует не просто «конституционная монархия», а «дуалистическая монархия», то Иордания, скорее, подойдет в качестве уже «центрального казуса», а не «пограничного примера».

Другой инструмент для своей методологии Финнис также заимствовал у Аристотеля. Речь идет о так называемом фокальном значении (Focal Meaning). По контрасту фокальное значение юридического термина уточняется посредством вовлечения в анализ примеров со слабо выраженным «наивысшим общим фактором». При этом в пограничных примерах некоторые «типичные черты» рассматриваемого явления могут и вовсе отсутствовать. Например, отсутствие в постсоветских республиках института ответственного (перед парламентом) министерства позволяет найти дополнительные аргументы как раз в пользу типичности для (нормальной) республики 
указанного института публичной власти. Однако, оценивая западные демократии в эпоху глобализации, исследователь может прийти к выводу, что институт ответственного министерства начинает деградировать и в тех странах, где он когда-то возник. Соответственно, указанный институт из фокального значения термина «республика» будет перемещен в кластер вторичных значений.

Финнис указывает на то, что не только обыватели, но и ученые мужи нередко не умеют опознать природу естественного права: «Естественное право не знает ни подъема, ни упадка, оно не может быть... призвано к ответу за катастрофы человеческого духа или зверства человеческой практики» [4, р. 24]. Итак, естественное право как таковое - это онтологическое (бытийное) единство и равенство представителей человеческого рода, имеющих врожденное и согласное представление о базовых человеческих ценностях. Онтологическим «якорем» естественного права служат такие социальные явления, как дружба, сотрудничество, взаимопомощь и социальная солидарность в широком смысле. Все они так или иначе вовлечены в механизм дистрибутивной, или распределительной, справедливости. Однако цель справедливости - не равенство, а общее благо, благосостояние всех членов сообщества.

Отечественные конституционалисты преимущественно безразличны к доктрине Фуллера о внутренней морали права и не ставят перед собой задачу интегрировать в систему российского правопорядка имманентную моральную компоненту. Напомним, что у Фуллера она состоит из восьми формальных, или процедурных, принципов: нормативности, публичности, неретроактивности, ясности, непротиворечивости, реализуемости, стабильности права, а также соответствия правоприменительных актов нормативным актам [5]. Они, как правило, видят только те из указанных принципов, которые имеют форму конституционных положений или представлены в виде норм федеральных конституционных законов.

Из восьми принципов внутренней морали права, по Фуллеру, конституционное право России заявляет лишь о некоторых, о большинстве же - «молчит». Бывают редкие исключения. Так, профрессор С.А. Авакьян выделяет принцип стабильности, как представляется, из самой идеологии конституционализма, а не из норм Конституции РФ. Аналогичную позицию занимают профессор С.И. Носов с соавторами Е.Ю. Догадайло и И.Д. Хутинаевым [6].

Однако и С.А. Авакьян рассматривает стабильность как характеристику отрасли конституционного права, а не как формальный принцип российского правопорядка вообще. Более того, мы видим, что стабильность конституции не совсем «стабильна»: она является лишь диалектическим моментом в паре с так называемым динамизмом: «Таким образом, вместе со стабильностью перед конституцией стоит вечная проблема динамизма...» [7, с. 164-165].

В контексте воззрений Фуллера также нуждается в корректировке тезис профессора М.В. Баглая о том, что «право и мораль должны обеспечивать неотвратимость наказания в отношении любого гражданина или должностного лица, посягнувшего на конституционные порядки» [8]. Во-первых, по Фуллеру, мораль (как социальная, так и личная) всегда предшествует праву, а не следует за ним. Во-вторых, только уголовно-правовая концепция права, а не гражданско-правовая концепция (не говоря уже о морали) имеет в виду «неотвратимость наказания».

Отсюда вытекают два малоутешительных следствия. Во-первых, принципы внутренней морали российского права нередко имеют разный иерархический статус. Так, если принцип публичности закона всеми презюмируется и считается общеотраслевым, то запрет обратной силы закона можно рассматривать скорее как базовый отраслевой принцип, а именно - принцип уголовного права. Поскольку неретроактивность явно в конституционном праве России не закреплена, то вопрос о применении или неприменении обратной силы закона в сфере конституционного права, а также других отраслей, за исключением уголовного права, остается открытым. Такова, впрочем, логика юридического позитивизма, господствующего во всяком конституционном праве, с которой решительно не согласен Фуллер.

Во-вторых, многие принципы внутренней морали права, по Фуллеру, даже не презюмируются, т. е. вовсе не известны отечественному конституционному праву. Например, принцип правовой стабильности не закреплен в отечественном правопорядке вообще и в конституционном праве в частности.

Итак, на нормативный каталог социально-экономических прав распространяются все восемь указанных принципов внутренней морали правопорядка по Фуллеру, независимо от того, закреплены они в конституционном праве России в явном виде или нет.

В контексте российской социологии права можно сделать вывод, что из этих восьми принципов часто «буксуют» принципы нормативности, непротиворечивости, реализуемости, стабильности, а также соответствия правоприменительных актов нормативным актам. В социальном законодательстве России принцип нормативности, как правило, сводится к принципу материальной нормативности без соответствующего процессуально-нормативного сопровождения. Другими 
словами, материальная норма о материнском капитале может оказаться «спящей» ввиду отсутствия нормативно закрепленной процедуры предоставления такого капитала.

В контексте теории Финниса социально-экономические права - это не просто права, позитивированные российскими законами. Данные права имеют естественно-правовую природу. Социально-экономические правопритязания граждан обладают статусом естественно-правовой справедливости, независимо от того, закреплены они в позитивном праве России или нет.

\section{Ссылки:}

1. См.: Фуллер Л. Мораль права / пер. с англ. Т. Даниловой. М., 2007.

2. См.: Финнис Дж. Естественное право и естественные права / пер. с англ. В.П. Гайдамака, А.В. Панихиной. М., 2012

3. Finnis J. Natural Law and Natural Rights. 2nd ed. Oxford, 2011. P. 10-11, 24.

4. Ibid. P. 24

5. Fuller L. The Morality of Law (1964). Revised ed. New Haven ; London, 1969. P. 39.

6. Авакьян С.А. Конституционное право России. М., 2005. Т. 1. С. 164-165 ; Конституционное право Российской Федерации / отв. ред. С.И. Носов. М., 2014. С. 13.

7. Авакьян С.А. Указ. соч. С. 164-165.

8. Баглай М.В. Конституционное право Российской Федерации. 6-е изд. М., 2007. С. 113.

\section{References:}

Avakyan, SA 2005, Constitutional law of Russia, Moscow, vol. 1, pp. 164-165, (in Russian).

Baglay, MV 2007, Constitutional law of the Russian Federation, 6th ed., Moscow, p. 113, (in Russian).

Finnis, J 2011, Natural Law and Natural Rights, 2nd ed. Oxford, pp. 10-11, 24.

Finnis, J, Gaydamak, VP \& Panikhina, AV (transl.) 2012, Natural Law and Natural Rights, Moscow, (in Russian).

Fuller, L 1969, The Morality of Law (1964), New Haven, London, p. 39.

Fuller, L \& Danilova, T (transl.) 2007, The Morality of Law, Moscow, (in Russian).

Nosov, SI (ed.) 2014, Constitutional law of the Russian Federation, Moscow, p. 13, (in Russian). 